\title{
Synthesis, Characterization and Biological Studies of New Linear Thermally Stable Schiff Base Polymers with Flexible Spacers
}

\author{
Farah Qureshi,* Muhammad Yar Khuhawar, Taj Muhammad Jahangir \\ and Abdul Hamid Channar
}

\author{
Institute of Advanced Research Studies in Chemical Sciences, University of Sindh, Jamshoro, Sindh, Pakistan \\ * Corresponding author: E-mail: farahqureshi94@yahoo.com \\ Tel: +92-229213213, +92-3313534844
}

Received: 15-09-2015

\begin{abstract}
Five new linear Schiff base polymers having azomethine structures, ether linkages and extended aliphatic chain lengths with flexible spacers were synthesized by polycondensation of dialdehyde (monomer) with aliphatic and aromatic diamines. The formation yields of monomer and polymers were obtained within 75-92\%. The polymers with flexible spacers of n-hexane were somewhat soluble in acetone, chloroform, THF, DMF and DMSO on heating. The monomer and polymers were characterized by melting point, elemental microanalysis, FT-IR, ${ }^{1} \mathrm{HNMR}$, UV-Vis spectroscopy, thermogravimetry (TG), differential thermal analysis (DTA), fluorescence emission, scanning electron microscopy (SEM) and viscosities measurement of their dilute solutions. The studies supported formation of the monomer and polymers and on the basis of these studies their structures have been assigned. The synthesized polymers were tested for their antibacterial and antifungal activities.
\end{abstract}

Keywords: Polymer synthesis, flexible spacers, thermal analysis, spectroscopy, SEM, biological activity

\section{Introduction}

Polymeric Schiff bases, which are also called polyazomethines, have been the subject of research for more than five decades. ${ }^{1-5}$ They are synthesized by polycondensation reaction between diamine and dialdehyde or diketone. ${ }^{6,7}$ They are an important class of compounds and find their application in different fields. They are useful complexing ligands for a number of transition metal ions ${ }^{8,9}$ and indicate paramagnetism, semiconducting and resistance to high energy. ${ }^{10-13}$ They are used to prepare composite materials having high resistance at high temperatures, thermostablizers, photoresistors, flame resistance materials, and components of electrochemical cells. ${ }^{14-16}$ The Schiff base polymers demonstrate antimicrobial activity against bacteria, yeast and fungi. ${ }^{17,18}$ Thus these can be used for the purification of industrial contaminants from heavy metals and microbiological organisms and are significant for environmental applications. These polymers are also being studied for the applications of optoelectronics. ${ }^{2,19-24}$ The poly Schiff bases may also form li- quid crystalline melts, the aromatic azomethine blocks being good mesogens. ${ }^{3,25,26}$

The polymeric Schiff bases are attractive polymers, but they indicate poor solubility in common organic solvents and are difficult to liquate for practical applications in various fields. ${ }^{27}$ However attempts have been made to improve the solubility of the polymers by polycondensation reactions with some aliphatic-aromatic aldehydes, ${ }^{15}$ incorporating phosphorus in the main chain, ${ }^{28}$ including oxygen atom in the repeat units, ${ }^{29}$ inserting solubility enhancing groups in the backbone ${ }^{30}$ and introducing alkyl or alkoxy groups in the ortho position of the aromatic ring. ${ }^{31}$ The present work examines the effect of increasing the flexible spacer between aromatic aldehydes, the introduction of ether linkage and heterocyclic ring in backbone on the solubility of the polymers. Five new polymers have been synthesized by polycondensation of a monomer with five different diamines and characterized by spectroscopic, thermal analysis and viscometric measurements and scanning electron microscopy (SEM). 


\section{Experimental}

\section{1. Chemicals}

4-hydroxybenzaldehyde(Aldrich Chemical Co. LtdSteinheim, Germany), 1,6-dibromohexane (Sigma Aldrich Inc, St.Louis USA), ethylenediamine (E-Merck, Germany), 1,3-propylenediamine (Fluka, switzerland), 4,4-diaminophenyl ether (Tokyo Chemical Industry Ltd, Tokyo, Japan), 2,6-diaminopyridine (Sigma-Aldrich, Germany), thiosemicarbazide (E.Merck, Darmstadt, Germany), N-N-dimethylformamide (DMF) (BDH AnalaR, England), dimethyl sulfoxide (DMSO) (BDH AnalaR, England), anhydrous sodium carbonate (Sigma-Aldrich, Germany), ethanol (Merck, Germany), toluene (Fluka Chemie, Switzerland), potassium hydroxide (E-Merck, Germany) and hydrochloric acid (Merck, Germany) were used. Freshly prepared double distilled water was used throughout the study.

\section{2. Equipment}

The elemental microanalysis of the polymers was carried out by Elemental Microanalysis Ltd, Devon, U.K. The mass spectra of the monomer (4,4'-hexamethylenebis(oxybenzaldehyde) (HOB) was recorded at the HEJ Research Institute of Chemistry, University of Karachi on Jeol JMS 600 mass spectrometer. The spectrophotometric studies in DMSO were recorded on double beam Lambda 35 spectrophotometer (Perkin Elmer, Singapur) within 500-200 nm with dual $1 \mathrm{~cm}$ quartz cuvettes. The spectrophotometer was controlled by the computer with Lambda 35 software. Infrared spectra of the compounds were recorded on Nicolet Avatar 330 FT-IR (Thermo Nicolet Corporation, U.S.A) with attanulated total reflectance, accessory (smart partner) within $4000-600 \mathrm{~cm}^{-1}$. The ${ }^{1} \mathrm{HNMR}$ spectra of the dialdehyde and polymers were recorded on a Bruker AVANCE-NMR spectrometers at $300 \mathrm{MHz}$ using DMF as solvent and tetramethylsilane (TMS) as internal reference at HEJ Research Institute of Chemistry, University of Karachi. Spectrofluorimetric studies were carried out on Spectrofluorophotometer RF-5301PC Series (Shimadzu Corporation, Kyoto, Japan) with $1 \mathrm{~cm}$ cuvettee. Thermogravimetry (TG) and differential thermal analysis (DTA) were carried on thermogravimetric thermal analyzer Pyris Diamond TG/ DTA (Perkin Elmer, Japan) from room temperature to $600{ }^{\circ} \mathrm{C}$ with a nitrogen flow rate 100 $\mathrm{ml} / \mathrm{min}$. Sample $5 \mathrm{mg}$ was placed in platinum crucible and recorded against alumina as reference with heating rate of $20{ }^{\circ} \mathrm{C} / \mathrm{min}$. The morphologies of the polymers were examined by scanning electron microscopy (SEM) using a JEOL JSM-6490LV instrument at Centre for Pure and Applied Geology, University of Sindh. The polymers were ground to powder and were placed on carbon conducting tape before recording their SEM. The SEM images were taken at an accelerating voltage of $20 \mathrm{KV}$.

The viscosity measurement of dialdehyde and polymers in DMF with 0.02-0.06 g/dl were recorded in the tem- perature range $383-323 \mathrm{~K}$ with an interval of $10 \mathrm{~K}$ by using a suspended level viscometer (Technico ASi 445). Each time $15 \mathrm{ml}$ of the solution was used and average flow time was noted from atleast three readings $(n=3)$. The flow time of the solvent was also recorded. A Gallenkamp viscometer water bath was used to control the temperature. The reduced viscosity $\left(\eta_{\text {red }}\right)$ was calculated by dividing specific viscosity $\left(\eta_{\mathrm{sp}}\right)$ by concentration $(\mathrm{d} / \mathrm{dl})$. The intrinsic viscosity $(\eta)$ was calculated by plotting $\eta_{\text {red }}$ against concentration and extraploting to zero concentration. The Huggins constant $\left(\mathrm{K}_{\mathrm{H}}\right)$ was calculated from the slope.

The antibacterial activity of polymers was measured against Escherichia coli, Shigella flexenari, Staphylococcus aureus and Pseudomonas aeruginosa. For antibacterial assay $2 \mathrm{mg}$ of polymers were separately dissolved in DMSO to get concentration of $50 \mu \mathrm{g} / \mathrm{disk}$. Percent inhibition of polymers was compared with the percent inhibition of drug ofloxacin. The antifungal activity of polymers was measured against Trichphyton rubrum, Candida albicans, Microsporum canis, Fusarium lini, Candida glabrata. The standard drug Amphotericin B was used for Aspergillus niger and Miconazole for the other fungal species. The concentration of polymers was $200 \mu \mathrm{g} / \mathrm{ml}$ of DMSO. Incubation was at $28^{\circ} \pm 1^{\circ} \mathrm{C}$ and incubation period was 7 days.

\section{3. Preperation of Monomer 4,4'-hexa- methylenebis(oxybenzaldehyde)(HOB)}

To $0.2 \mathrm{~mol}$ (24.5 g) of 4-hydydroxybenzaldehyde into $250 \mathrm{ml}$ round bottom flask equipped with a condenser was added $0.25 \mathrm{~mol}(25 \mathrm{~g})$ anhydrous sodium carbonate. The contents were stirred with magnetic bar and added 0.1 mol (15.38 ml) of 1,6-dibromohexane dissolved in $25 \mathrm{ml}$ DMF. The reaction mixture was refluxed (about $150{ }^{\circ} \mathrm{C}$ ) for $5 \mathrm{~h}$ under continuous stirring. After cooling, the product was poured into 21 of cold distilled water $\left(5^{\circ} \mathrm{C}\right)$ and allowed precipitate to settle. The product was filtered and washed with $\mathrm{KOH}(0.1 \mathrm{M})$ and then three times with water. The product was dried and then recrystallised from ethanol. M.p $=100{ }^{\circ} \mathrm{C}$, yield $92 \%, \mathrm{C}_{20} \mathrm{H}_{22} \mathrm{O}_{4}$, mass spectrum $\mathrm{m} / \mathrm{z}$ (rel. intensity \%) $\mathrm{M}^{+} 326$ (3.5), 205(4.7), 177(3.0), 135(9.0), 121(38.3), 83 (53.6), 55.1 (100). FTIR $\mathrm{cm}^{-1}$ (Rel. intensity) 2946(w), 2856(w), 2745(w), 1684(s), 1595(s), 1507(s), 1479(s), 1463(m), 1399(m), 1309(m), 1250(s), 1213(m), 1152(s), 1111(w), 1008(s), 831(s), 793(m), 729(w), 715(w). ${ }^{1} \mathrm{HNMR}$ (DMSO), $\delta \mathrm{ppm}$ 1.482, $1.763(\mathrm{t}), 4.089(\mathrm{t}), 7.103(\mathrm{~d}), 7.840(\mathrm{~d}), 9.840$. UV, $\lambda$-max, nm (عL.mole $\left.{ }^{-1} \mathrm{~cm}^{-1}\right) 283$ (32500).

\section{4. Preparation of Polymers}

The five Schiff base polymers were synthesized by following same general procedure. An equimolar mixture of $5 \mathrm{mmol}$ of diamine (ethylenediamine, 1,3-propyplenediamine, 2,6-diaminopyridine, 4,4'-diaminophenyl ether or thiosemicarbazide) dissolved in $10 \mathrm{ml}$ DMF and 
$5 \mathrm{mmol}$ dialdehyde (HOB) dissolved in $20 \mathrm{ml}$ DMF were transferred into a $250 \mathrm{ml}$ round bottom flask equipped with a condenser and a magnetic stir bar. Then 3 drops of 0.1 mol hydrochloric acid were added. The reaction mixture was refluxed with continuous stirring for $6 \mathrm{~h}$ under nitrogen atmosphere. The product was added to $200 \mathrm{ml}$ water and allowed precipitate to settle. The products was filtered and washed with ethanol and then dried.

\section{4. 1. Poly-4,4'-hexamethylenebis(oxybenzal- dehyde)ethylenediimine (PHOBen)}

M.p $=220{ }^{\circ} \mathrm{C}$, yield 95\%, calculated for $\left(\mathrm{C}_{22} \mathrm{H}_{26} \mathrm{~N}_{2} \mathrm{O}_{2}\right)_{\mathrm{n}} \% \mathrm{C}=75.42, \mathrm{H}=7.42, \mathrm{~N}=8.00$, found \% $\mathrm{C}=75.62, \mathrm{H}=7.70, \mathrm{~N}=8.43$. FT-IR, $\mathrm{cm}^{-1}$ (rel. intensity), 2940(w), 2825(w), 1685(w), 1639(m), 1603(s), 1575(m), 1509(s), 1472(w), 1305(m), 1240(s), 1165(s), 1110(w), 1018(m), 830(s), 806(w). ${ }^{1}$ HNMR (DMSO), $\delta$ ppm 1.25, $1.50,1.79,4.091(\mathrm{t}), 7.104(\mathrm{~d}), 7.840(\mathrm{~d}), 9.850$. UV (DMSO), $\lambda \max$ (1\% absorptivity) 274(189.4).

\section{4. 2. Poly-4,4'-hexamethylenebis(oxybenzal- dehyde) 1,3-propylenediimine (PHOBPR)}

M.p $=130{ }^{\circ} \mathrm{C}$ yield $80 \%$ calculated for $\left(\mathrm{C}_{23} \mathrm{H}_{28} \mathrm{~N}_{2} \mathrm{O}_{2}\right)_{\mathrm{n}}$. $\% \mathrm{C}=75.82, \mathrm{H}=7.69, \mathrm{~N}=7.69$, found $\% \mathrm{C}=74.48, \mathrm{H}=7.52$, $\mathrm{N}=7.13$, FT-IR $\mathrm{cm}^{-1}$. (rel. intensity), 2939(w), 2825(w), 1686(w), 1603(s), 1577(s), 1508(s), 1465(w), 1305(m), 1247(s), 1166(s), 1159(s), 1113(m), 1070(w), 1017(m), 998(s), 951(m), 936(w), 886(w), 830(s), 787(w), 727(w), 701(w), 687(w). ${ }^{1}$ HNMR (DMSO), $\delta$ ppm 1.21, 1.48, 1.75, 4.091(t), 7.104(d), 7.840(d), 9.850. UV (DMSO) $\lambda$-max nm (1\% absorptivity), 281(251.3).

\section{4. 3. Poly-4,4'-hexamethylenebis(oxybenzaldehy- de)4,4'-diaminophenylether (PHOBPh)}

M.p $=260{ }^{\circ} \mathrm{C}$ (decomposed), yield $75 \%$, calculated for $\left(\mathrm{C}_{32} \mathrm{H}_{30} \mathrm{~N}_{2} \mathrm{O}_{2}\right)_{\mathrm{n}}$. \% $=75.55, \mathrm{H}=6.29, \mathrm{~N}=5.51$, found $\%$
$\mathrm{C}=75.88, \mathrm{H}=6.33, \mathrm{~N}=5.56$; FT-IR, $\mathrm{cm}^{-1}$ (rel.intensity), 2940(w), 2866(w), 1683(w), 1620(s), 1603(s), 1574(s), 1507(s), 1492(s), 1474(s), 1419(w), 1398(w), 1305(m), 1243(s), 1282(w), 1242(s), 1188(w), 1163(s), 1106(m), 1019(m), 977(w), 959(w), 872(m), 847(m), 823(m), 804(w), 789(w), 729(m), 714(m), 689(m), 679(w),

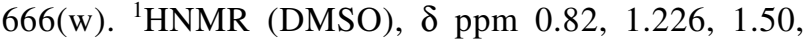
4.092(t), 7.105(d), 7.840(d), 9.850. UV (DMSO), $\lambda$-max nm (1\% absorptivity) 276(373.2), 331(52.35).

\section{4. 4. Poly-4,4'-hexamethylenebis(oxybenzal- dehyde)2,5-diiminopyridine (PHOBP)}

M.p $=280{ }^{\circ} \mathrm{C}$ (decomposed), yield $85 \%$, calculated for $\left(\mathrm{C}_{25} \mathrm{H}_{25} \mathrm{~N}_{3} \mathrm{O}_{2}\right)_{\mathrm{n}} . \% \mathrm{C}=68.96, \mathrm{H}=6.66, \mathrm{~N}=10.00$, found $\% \mathrm{C}=67.00, \mathrm{H}=6.33, \mathrm{~N}=10.86$. FT-IR, $\mathrm{cm}^{-1}$ (rel. intensity) 2932(w), 2865(w), 1671(w), 1599(s), 1572(s), 1507(s), 1444(s), 1301(w), 1236(s), 1159(s), 1110(w), 1008(m), 828(m), 787(w), 721(w), 701(w), 691(w). ${ }^{1} \mathrm{HNMR}$ (DMSO) $\delta \mathrm{ppm} \mathrm{1.484,} \mathrm{1.765,} \mathrm{2.72,}$ 2.880, 4.091(t), 7.104(d), 7.851(t), 9.850. UV+Vis (DM$\mathrm{SO}), \lambda$-max $\mathrm{nm}$ (1\% absorptivity) 227(442.3), 327(114.1), 444(71.1).

\section{4. 5. Poly-4,4'-hexamethylenebis (oxybenzaldehyde)thiosemicarbazone (PHOBTSc)}

M.p $=265{ }^{\circ} \mathrm{C}$ (decomposed), yield $76 \%$, calculated for $\left(\mathrm{C}_{21} \mathrm{H}_{21} \mathrm{~N}_{3} \mathrm{O}_{2} \mathrm{~S}\right)_{\mathrm{n}}$. \% $\mathrm{C}=66.14, \mathrm{H}=6.03, \mathrm{~N}=11.02$, found $\% \mathrm{C}=67.34, \mathrm{H}=6.60, \mathrm{~N}=10.74$. FT-IR $\mathrm{cm}^{-1}$ (Rel.Intensity) 2944(w), 2866(w), 1683(m), 1599(s), 1573(s), 1508(s), 1471(w), 1422(s), 1395(m), 1307(w), 1244(s), 1159(s), 1108(w), 1019(m), 959(w), 868(s), 829(s), 802(s), 759(m), 729(m), 689(m). ${ }^{1} \mathrm{HNMR}$ (DMSO) $\delta \mathrm{ppm} \mathrm{1.22,} \mathrm{1.483,} \mathrm{1.761,} \mathrm{4.059(m),} \mathrm{7.027(m),}$ $7.830(\mathrm{~m}), 9.850,11.278$. UV (DMSO), $\lambda$-max (1\% absorptivity) 288(329.2), 330(301.2).

a)

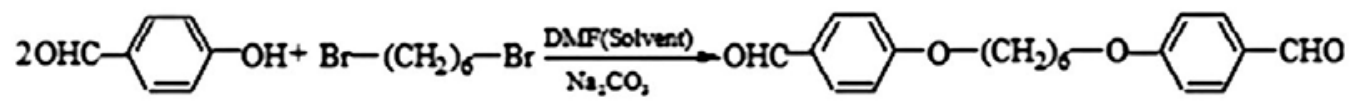

b)

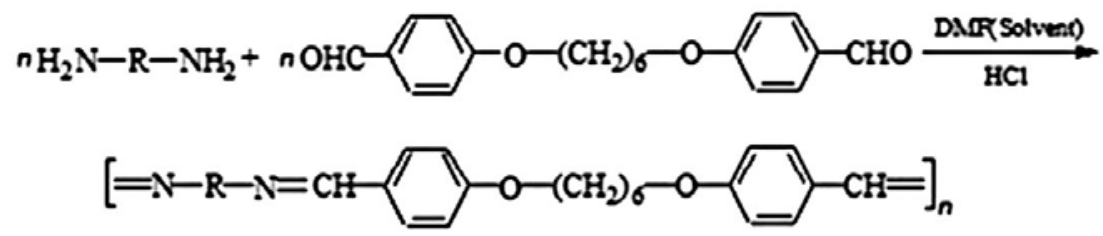

I. PHOBen: $\mathrm{R}=\mathrm{CH}_{2} \cdot \mathrm{CH}_{2}$ II. PHOBPR: $\mathrm{R}=\mathrm{CH}_{2} \cdot \mathrm{CH}_{2} \cdot \mathrm{CH}_{2}$ III. PHOBPh: $\mathrm{R}=\mathrm{C}_{8} \mathrm{H}_{4} \mathrm{OC}_{6} \mathrm{H}_{4}$ IV. $\mathrm{PHOBP}: \mathrm{R}=\mathrm{C}_{5} \mathrm{H}_{3} \mathrm{~N} \quad$ V. $\mathrm{PHOBTSC}: \mathrm{R}=\mathrm{CS} . \mathrm{NH}$

Figure 1. Reaction scheme (a) synthesis of monomer HOB and (b) synthesis of polymers 


\section{Results and Discussion}

\section{1. Synthesis of Monomer and Polymers}

The general reaction scheme for the preparation of the monomer $\mathrm{HOB}$ and five polymers with their possible structure is given in (Figure 1).

The monomer was easily prepared following a general reaction scheme as reported ${ }^{32}$ and was obtained in good yield (92\% theoretical). The polymers are also prepared by polycondensation by warming together the equimolar solutions of monomer and diamino-compounds in the presence of a few drops of acid. The compounds were obtained in good yield (76-95\%).

\section{2. Solubility}

The solubility of the monomer and the polymers were examined in water, ethanol, acetone, chloroform, THF, DMF and DMSO. The monomer HOB was soluble in most of the solvents except water, but the polymers were somewhat soluble in DMF and DMSO (Table 1). Among the polymers PHOBP indicated lowest solubility within the solvents examined, due to the incorporation of aromatic pyridyl ring in the polymer.

\section{3. E.I Mass Spectrum of Monomer HOB}

The mass spectrum of the monomer indicated $\mathrm{M}^{+}$at $\mathrm{m} / \mathrm{z}$ at 326 , followed by fragment peak at $\mathrm{m} / \mathrm{z} 205$ corresponding to $\left[\mathrm{M}-\left(0 . \mathrm{C}_{6} \mathrm{H}_{4} \cdot \mathrm{CHO}\right)\right]^{+}$. Other main fragments were observed at $\mathrm{m} / \mathrm{z} 177,135$ and 121 corresponding to [CHO.C $\mathrm{CH}_{4}$.O. $\left.\left(\mathrm{CH}_{2}\right)_{4}\right]^{+}, \quad\left[\mathrm{CHO} . \mathrm{C}_{6} \mathrm{H}_{4} \cdot \mathrm{O}-\mathrm{CH}_{2}\right]^{+}$and $\left[\mathrm{CHO}_{6} \mathrm{C}_{6} \mathrm{H}_{4} \cdot \mathrm{O}\right]^{+}$. The peaks at $\mathrm{m} / \mathrm{z} 83(54 \%)$ and $55(100 \%)$ were due to $\mathrm{C}_{6} \mathrm{H}_{11}$ and $\mathrm{C}_{4} \mathrm{H}_{7}$ (See supplementary data)

\section{4. FT-IR Spectroscopy}

The FTIR of the monomer (HOB) indicated a strong band at $1683 \mathrm{~cm}^{-1}$ for $v \mathrm{C}=\mathrm{O} 1595$ and $1507 \mathrm{~cm}^{-1}$ for $v \mathrm{C}=\mathrm{C}$ aromatic rings and at $1250,1069 \mathrm{~cm}^{-1}$ for $\mathrm{C}-\mathrm{O}-\mathrm{C}$ vibrations. The FT-IR of the polymers PHOBen, PHOBPR, PHOBPh, PHOBP and PHOBTSc indicated weak to medium intensity band within $1671-1686 \mathrm{~cm}^{-1}$ due to $v \mathrm{C}=\mathrm{O}$ contributed from end on group, followed by strong to medium intensity band within $1599-1651 \mathrm{~cm}^{-1}$ due to $v \mathrm{C}=\mathrm{N}$ vibrations. Two to three bands were visible within $1603-1491 \mathrm{~cm}^{-1}$ due to aromatic rings of the polymers. Two bands were observed in the polymers within $1236-1281 \mathrm{~cm}^{-1}$ and $1008-1018 \mathrm{~cm}^{-1}$ due to asymmetric and symmetric $\mathrm{C}-\mathrm{O}-\mathrm{C}$ vibrations. A number of bands were observed within $997-670 \mathrm{~cm}^{-1}$ due to in plane and out of plane $\mathrm{C}-\mathrm{H}$ vibrations of aromatic ring systems (See supplementary data)

\section{5. Proton NMR Spectroscopy}

${ }^{1} \mathrm{HNMR}$ (DMSO) of monomer HOB indicated $\delta$ ppm at 9.850 for $\mathrm{CHO}$, two doublets at 7.840 and 7.103 due to aromatic $\mathrm{C}-\mathrm{H}$ protons, triplet at 4.089 for $\mathrm{O}-\mathrm{CH}_{2}-$, triplet at 1.763 and singlet at 1.482 for $\mathrm{CH}_{2}$ groups. ${ }^{1} \mathrm{HNMR}$ of PHOBTSc (DMSO) indicated $\delta \mathrm{ppm}$ at 11.278 for $-\mathrm{NH}, 9.850$ for $\mathrm{N}=\mathrm{CH} / \mathrm{HC}=\mathrm{O}$, multiplets at 7.830 and 7.027 for aromatic $\mathrm{C}-\mathrm{H}$ protons, multiplet at 4.059 for $\mathrm{O}-\mathrm{CH}_{2}-$, and 1.761 and 1.483 for $\mathrm{CH}_{2}$ groups (See supplementary data). Similarly PHOBen and PHOBP showed $\delta \mathrm{ppm}$ at 9.850-9.851 for $\mathrm{N}=\mathrm{CH} /$ $\mathrm{HC}=\mathrm{O}, 7.104 \&$ 7.840, and 7.104(d) \& 7.851(d) for aromatic $\mathrm{C}-\mathrm{H}$ protons, 4.091(t) for $\mathrm{O}-\mathrm{CH}_{2}, 2.880,2.72$, $1.765,1.484 \mathrm{ppm}$ for $-\mathrm{CH}_{2}$ groups. The polymers PHOBPR and PHOBPh also indicate a similar pattern and support the structures assigned.

\section{6. UV-Vis Spectroscopy}

The spectrophotometric study of monomer and polymers was carried out in DMSO against the solvent and the monomer HOB indicated a broad band centered at $283.0 \mathrm{~nm}$ with molar absorptivity $3.2 \times 10^{4} \mathrm{~L} \cdot \mathrm{mole}^{-1}$ $\mathrm{cm}^{-1}$ due to $\pi-\pi^{*}$ transition within aromatic ring systems. The polymers PHOBen and PHOBPR indicated a broad band each with maximum absorbance at $274 \mathrm{~nm}$ and 281 nm, with $1 \%$ absorptivity 189.4 and 251.3 respectively. The polymers PHOBPh and PHOBTSc indicated two bands and polymer PHOBP three bands within their absorption spectra. The increase in the number of bands in

Table 1: Solubility of monomer (HOB) and polymers in different solvents at the concentration of $5 \mathrm{mg} / 5 \mathrm{ml}$

\begin{tabular}{|c|c|c|c|c|c|c|c|c|}
\hline \multirow{2}{*}{ S. No } & \multirow{2}{*}{ Compound } & \multicolumn{7}{|c|}{ Solubility in different solvents } \\
\hline & & $\mathrm{H}_{2} \mathrm{O}$ & Ethanol & Acetone & Chloroform & THF & DMF & DMSO \\
\hline 1. & HOB & IS & $\mathrm{S}$ & $S$ & $\mathrm{~S}$ & $S$ & $S$ & $S$ \\
\hline 2. & PHOBen & IS & IS & IS & PS & IS & $\mathrm{S}(\Delta)$ & $\mathrm{S}(\Delta)$ \\
\hline 3. & PHOBPR & IS & IS & IS & S & PS & $\mathrm{S}(\Delta)$ & $\mathrm{S}(\Delta)$ \\
\hline 4. & $\mathrm{PHOBPh}$ & IS & IS & PS & PS & IS & PS & $\mathrm{S}(\Delta)$ \\
\hline 5. & PHOBP & IS & IS & IS & IS & IS & IS & $\mathrm{S}(\Delta)$ \\
\hline 6. & PHOBTSc & IS & IS & PS & PS & PS & PS & $\mathrm{S}(\Delta)$ \\
\hline
\end{tabular}

$\mathrm{S}=$ Soluble, $\mathrm{S}(\Delta)=$ Soluble on heating, $\mathrm{PS}=$ Partially soluble, $\mathrm{IS}=$ Insoluble 
the polymers $\mathrm{PHOBPh}$, PHOBTSc and PHOBP may be due to transition $\pi-\pi^{*}$ in conjugated azomethine with phenyl, thiosemicarbazone or pyridine ring systems (See supplementary data).

\section{7. Thermal Analysis}

The thermal analysis (thermogravimetry (TGA) and differential thermal analysis) (DTA) of the monomer and the polymers were recorded in nitrogen atmosphere. TG of HOB indicated single stage weight loss of $95 \%$ within $250-500{ }^{\circ} \mathrm{C}$ with maximum rate of weight loss $\left(\mathrm{T}_{\max }\right)$ at $362{ }^{\circ} \mathrm{C}$. DTA showed three endotherms, first at $112{ }^{\circ} \mathrm{C}$ for melting point and two broad endotherm with their maximum at $365{ }^{\circ} \mathrm{C}$ and $475{ }^{\circ} \mathrm{C}$ for vaporization/ decomposition of the compound (See supplementary data). TG of PHOBen indicated three stages weight loss with $8 \%$ weight loss within $225-328{ }^{\circ} \mathrm{C}$ followed by $15 \%$ weight loss within $330-445{ }^{\circ} \mathrm{C}$ and further loss of $35 \%$ within 446-500 ${ }^{\circ} \mathrm{C}$. The maximum rate of weight loss $\left(\mathrm{T}_{\max }\right)$ was at $462{ }^{\circ} \mathrm{C}$. DTA showed an endotherm at $125^{\circ} \mathrm{C}$ for loss of solvent and melting endotherm at $200^{\circ} \mathrm{C}$. A broad decomposition exotherm was observed at $345^{\circ} \mathrm{C}$. TG of PHOBPR indicated 3 stages weight loss with $5 \%$ within $225-310^{\circ} \mathrm{C}$ followed by $20 \%$ weight loss within $311-440{ }^{\circ} \mathrm{C}$ and $35 \%$ further loss within $441-500{ }^{\circ} \mathrm{C}$. Derivative thermogravimetry indicated $\mathrm{T}_{\max }$ at $465^{\circ} \mathrm{C}$. DTA indicated melting endotherm at $125{ }^{\circ} \mathrm{C}$ and two decomposition exotherms at $355^{\circ} \mathrm{C}$ and $440{ }^{\circ} \mathrm{C}$. TG of PHOBPh indicated a single stage weight loss of $50 \%$ within $250-500{ }^{\circ} \mathrm{C}$. DTG showed $\mathrm{T}_{\max }$ at $446{ }^{\circ} \mathrm{C}$. DTA indicated two decomposition exotherms at $275{ }^{\circ} \mathrm{C}$ and $440^{\circ} \mathrm{C}$. TG of PHOBP indicated initial loss of $5 \%$ within $35-200{ }^{\circ} \mathrm{C}$ may be due to the loss of solvent followed by $14 \%$ weight loss within $221-425{ }^{\circ} \mathrm{C}$ and further loss of $20 \%$ within $452-500^{\circ} \mathrm{C}$. DTG indicated $\mathrm{T}_{\max }$ at $452{ }^{\circ} \mathrm{C}$. DTA indicated a decomposition exotherm at $415{ }^{\circ} \mathrm{C}$. TG of PHOBTSc indicated also three stages weight losses with $12 \%$ loss within $211-340{ }^{\circ} \mathrm{C}$, followed by $23 \%$ loss within $341-440{ }^{\circ} \mathrm{C}$ and further loss of $20 \%$ within $441-500{ }^{\circ} \mathrm{C}$. DTG showed $\mathrm{T}_{\max }$ value at $450{ }^{\circ} \mathrm{C}$.
DTA show a decomposition exotherm at $352{ }^{\circ} \mathrm{C}$ (See Supplementary data). The results support the enhancement in thermal stability of the polymers with higher $\mathrm{T}_{\max }$ value as compared to the monomer HOB.

\section{8. Fluorescence Emission}

The monomer $\mathrm{HOB}$ and its polymers contained aromatic ring system and were examined for the fluorescence properties. The results are summarized in Table 2.

The monomer HOB indicated fluorescence with excitation $313 \mathrm{~nm}$ and $378 \mathrm{~nm}$ and emission at 362, 413 and $436 \mathrm{~nm}$. The Polymers also indicated 1 to 2 emission bands with verifying relative intensities and the results support that the prepared materials are fluorescent compounds (See Supplementary data).

\section{9. Scanning Electron Microscopy (SEM)}

The morphologies of the polymers were recorded at $100 \mu \mathrm{m}, 50 \mu \mathrm{m}$ and $10 \mu \mathrm{m}$ resolving power. The polymers PHOBen was observed as globular (Figure 2a), but polymer PHOBPR was fibrous with average length of rods $52.2 \mu \mathrm{m}$ and width $3.4 \mu \mathrm{m}(\mathrm{n}=3)$ (Figure 2b), PHOBPh and PHOBTSc were observed to be amorphous, with average holes width of $9.06 \mu \mathrm{m}(\mathrm{n}=3)$ for PHOBPh (Figure 2c). The surface of PHOBP was indicated as rough with rigid structure (Figure 2d).

\section{10. Viscosity Measurement}

The monomer HOB and its polymers were examined for viscous flow of their dilute solutions within temperatures 293-333 K to examine the effect of polymerization. HOB indicated reduced viscosity within $0.287-0.377 \mathrm{dl} / \mathrm{g}$, which increased to $0.610-0.748 \mathrm{dl} / \mathrm{g}$ and $0.881-0.984 \mathrm{dl} / \mathrm{g}$ in PHOBen and PHOBPh respectively. The intrinsic viscosity which is dependent on the size and shape of molecule indicated values for HOB within

Table 2: Spectrofluorometric determination of monomer (HOB) and polymers.

\begin{tabular}{lcccc}
\hline Compound & $\begin{array}{c}\text { Concentration } \\
\text { in } \boldsymbol{\mu g} / \mathbf{m l}\end{array}$ & $\begin{array}{c}\text { Excitation } \\
\text { Wavelength(nm) }\end{array}$ & $\begin{array}{c}\text { Emission } \\
\text { wavelength(nm) }\end{array}$ & $\begin{array}{c}\text { Relative intensity } \\
\text { of emission }\end{array}$ \\
\hline HOB & 20 & 313 & 362 & 949 \\
& & 378 & 413 & 162 \\
PHOBen & 50 & 309 & 336 & 188 \\
PHOBPR & & & 620 & 165 \\
PHOBPh & 50 & 277 & 342 & 35 \\
PHOBP & 20 & 280 & 388 & 216 \\
& 20 & 310 & 380 & 139 \\
PHOBTSc & 50 & 312 & 450 & 104 \\
& & & 384 & 622 \\
\hline
\end{tabular}



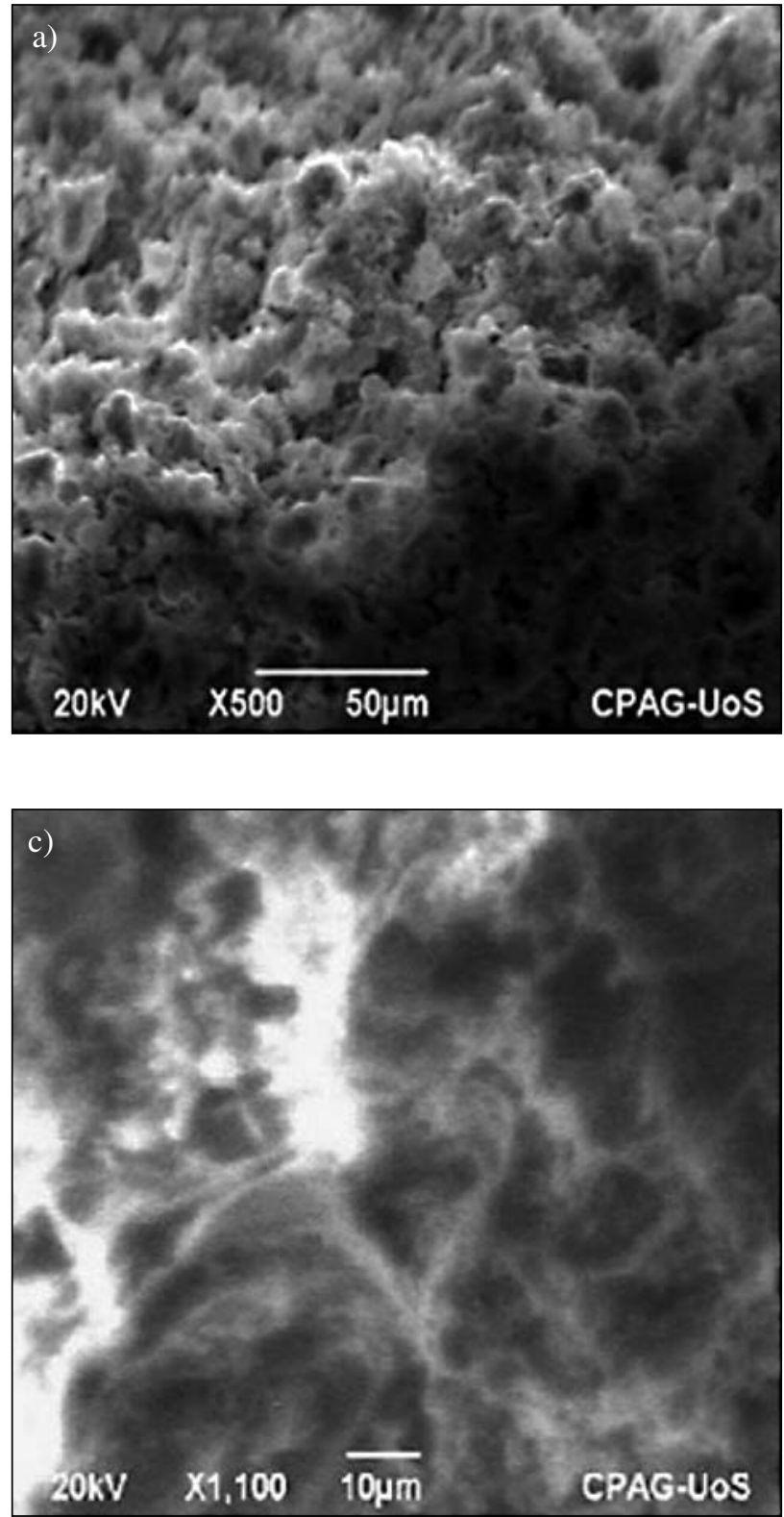

b)

\section{$20 \mathrm{kV} \quad \mathrm{X} 1,000 \quad 10 \mu \mathrm{m}$}

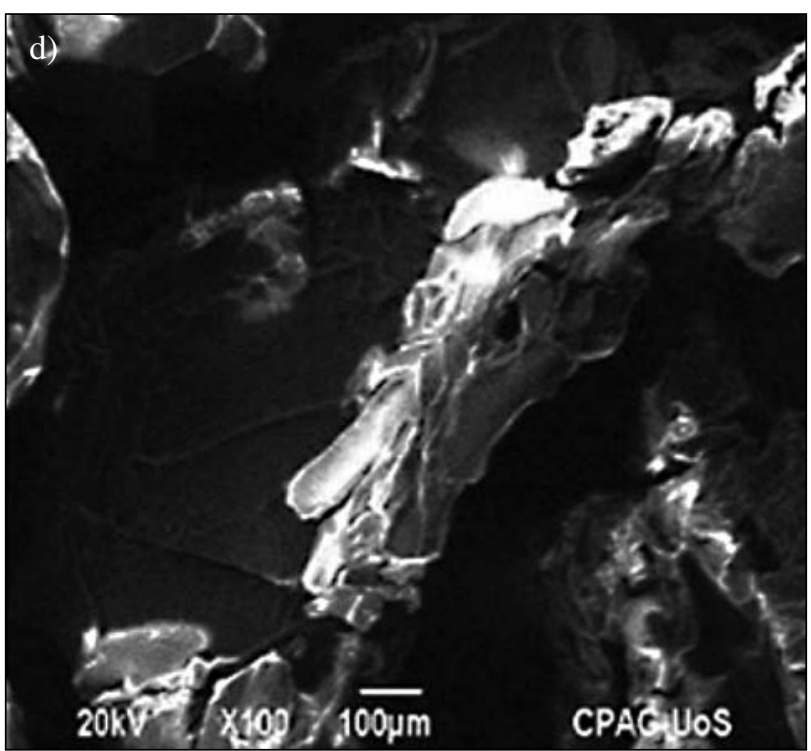

Figure. 2 SEM Images of (a) PHOBen (b) PHOBPR (c) PHOBPh and (d) PHOBP conditions as experimental

$0.249-0.314 \mathrm{dl} / \mathrm{g}$ as compared to $0.570-0.686 \mathrm{dl} / \mathrm{g}$ and $0.850-0.932 \mathrm{dl} / \mathrm{g}$ for PHOBen and PHOBPh polymers respectively due to increase in the molecular mass on polymerization. The values of Huggins constant $\left(\mathrm{K}_{\mathrm{H}}\right)$ depend upon solvent properties for the compounds and were within the range $1.06-1.25,1.01-1.97$ and $0.86-1.50$ for HOB, PHOBen and $\mathrm{PHOBPh}$ respectively above the values of 0.5 indicating DMF as poor solvent for the compounds.

\section{11. Antimicrobial Assay}

The synthesized polymers were tested for their antifungal and antibacterial activities. The polymers show non-significant antifungal activity. The polymers PHOBen, PHOBPR and PHOBP show some antibacterial activity and the results are summarized in Table 3 .

\section{Conclusion}

Five new polymers have been synthesized by single stage polycondensation reaction in solution in DMF. The polymers are characterized by elemental microanalysis, FT-IR, UV-Vis, ${ }^{1} \mathrm{HNMR}$ and dilute solution viscosities measurement. The polymers indicated different morphologies from globular, fibrous, amorphous to rough with rigid structures observed from SEM studies. The polymers 
Table 3: Antibacterial activities of polymers

\begin{tabular}{|c|c|c|c|c|c|c|}
\hline \multirow{2}{*}{ Name of Bacteria } & \multicolumn{6}{|c|}{ Percent $(\%)$ inhibition of Polymers and standard drug (ofloxacin) } \\
\hline & PHOBen & PHOBPR & PHOBPh & РНОВР & PHOBTSc & Ofloxacin \\
\hline Escherichia coli & 11.98 & 10.682 & 5.801 & - & - & 82.294 \\
\hline Shigella flexenari & 24.983 & - & - & - & - & 84.172 \\
\hline Staphylococcus aureus & - & 16.536 & 5.058 & 17.999 & - & 83.012 \\
\hline Pseudonomas aureus & 3.830 & - & - & - & 1.713 & 85.274 \\
\hline
\end{tabular}

The negative (-) sign indicates no inhibition against bacteria

indicate better thermal stability then monomer and all the compounds show fluorescence within UV-Vis region. The polymers contain biological active azomethine functional groups, but indicated poor antifungal and antifungal activity.

\section{Acknowledgement}

We like to thank University of Sindh for the payments for elemental microanalysis and Higher Education Commission, Islamabad for financial assistance for antifungal and antibacterial studies.

\section{References}

1. G. F. D'alelio, J. V. Crivello, R.K. Schoenig, T.F. Huemmer, J. Macromol. Sci.Chem. A. 1967, 1, 1161-1249. http://dx.doi.org/10.1080/10601326708053766

2. M. L. Petrus, R. K. M. Bouwer, U. Lafont, D. H. K. Murthy, R. J. P. Kist, M. L. Böhm, Y. Olivier, T. J. Savenije,L. D. A. Siebbeles, N. C. Greenham, T. J. Dingemans, T. J. Polym. Chem. 2013, 4, 4182-4191. http://dx.doi.org/10.1039/c3py00433c

3. A. Iwan, Renewable Sustainable Energy Rev. 2015, 52, 65-79. http://dx.doi.org/10.1016/j.rser.2015.07.078

4. A. Iwan, D. Sek, Prog. Polym. Sci. 2008, 33, 289-345. http://dx.doi.org/10.1016/j.progpolymsci.2007.09.005

5. A. Iwan, E. Schab-Balcerzak, D. Pociecha, M. Krompiec, M. Grucela, P. Bilski, M. Klosowski, H. Janeczek, Opt. Mater. 2011, 34, 61-74. http://dx.doi.org/10.1016/j.optmat.2011.07.004

6. M. Tuncel, A. Özbülbül, S. Serin, Reactive and Functional polymers. 2008, 68, 292-306. http://dx.doi.org/10.1016/j.reactfunctpolym.2007.08.012

7. A. Iwan, B. Boharewicz, I. Tazbir, M. Malinowski, M. Filapek, T. Klab, B. Luszczynska, I. Glowacki, K. P Korona, M. Kaminska, J. Wojtkiewicz, M. Lewandowska, A. Hreniak, Sol. Energy, 2015, 117, 246-259. http://dx.doi.org/10.1016/j.solener.2015.03.051

8. N. Nishat, S. A. Khan, R. Rasool, S. Parveen, J. Inorg. Organomet. Polym. 2012, 22, 455-463. http://dx.doi.org/10.1007/s10904-011-9592-5
9. A. Shah, M. Y. Khuhawar, A. A. Shah, Iran. Polym. J. 2012, 21,325-334.

10. S. C. Suh, S. C. Shim, Synth. Met. 2000, 114, 91-95. http://dx.doi.org/10.1016/S0379-6779(00)00234-4

11. B. A. Mamedov, Y. A.Vidadi, D. N. Alieva, A. V. Ragimov, Polym. Int. 1997, 43, 126-128.

http://dx.doi.org/10.1002/(SICI)1097-0126(199706)43:2 $<126:$ :AID-PI723>3.0.CO;2-\#

12. K. Ayesha, T. H. Syed, Iran. Polym. J.2013, 22, 175-185.

13. A. Iwan, D. Sek, Prog. Polym. Sci. 2011, 36, 1277-1325. http://dx.doi.org/10.1016/j.progpolymsci.2011.05.001

14. N. Nishat, R. Rasool,S. Parveen, S. A. Khan. J. Appl. Polym. Sci. 2011, 122, 2756-2764. http://dx.doi.org/10.1002/app.34100

15. M. Grigoras, C. O. Catanescu, J. Macromol. Sci. Part CPolym Rev. 2004, 44, 131-173. http://dx.doi.org/10.1081/MC-120034152

16. K. I. Aly, A. A. Khalaf, J. Appl. Polym. Sci. 2000, 77, 12181229.

http://dx.doi.org/10.1002/1097-4628(20000808)77:6<1218: :AID-APP6>3.0.CO;2-G

17. I. Kaya, A. R. Vilayetoğlu, H. J. Topak, App. Polym. Sci. 2002, 85, 2004-2013. http://dx.doi.org/10.1002/app.10815

18. I. Kaya, H. O. Demir, A. R. Vilayetoğlu, Synth. Met. 2002, 126, 183-191(2002) http://dx.doi.org/10.1016/S0379-6779(01)00501-X

19. B. Jarzabek, J. Weszka, M. Domanski, J. Jurusik, J. Cisowski, Journal of Non-crystalline Solids. 2006, 352, 1660- 1662. http://dx.doi.org/10.1016/j.jnoncrysol.2005.11.107

20. M. S. Weaver, D. D. C. Bradley, Synth. Met. 1996, 83, 61-66. http://dx.doi.org/10.1016/S0379-6779(97)80053-7

21. A. Iwan, M. Palewicz, A. Sikora, J. Chmielowiec, A. Hreniak, G. Pasciak, P. Bilski, Synth. Met. 2010, 160, 18561867. http://dx.doi.org/10.1016/j.synthmet.2010.06.029

22. D. Sek, B. Jarzabek, E. Grabiec, B. Kaczmarczyk, H. Janeczek, A. Sikora, A. Hreniak, M. Palewicz, M. Lapkowski, K. Karon, A. Iwan, Synth. Met. 2010, 160, 2065-2076. http://dx.doi.org/10.1016/j.synthmet.2010.07.026

23. A. Iwan, E. Schab-Balcerzak, K. P Korona, S. Grankowska, M. Kaminska, Synth. Met. 2013, 185-186, 17-24. http://dx.doi.org/10.1016/j.synthmet.2013.10.008

24. A. Iwan M. Palewicz, A. Chuchmala, L. Gorecki, A.Sikora, B. Mazurek, G. Pasciak, Synth. Met. 2012, 162, 143-153. 
25. H. Naarmann, P. Strohriegel, in: H. R. Kricheldorf, (Ed.), Conducting and Photoconducting Polymers, Handbook of Polymer Synthesis, Part B, New York, Marcel Dekker, Inc, 1992, pp. 1353-1435.

26. M. A. Hussein, M. A. Abdel Rehman, A. M. Asiri, K. A. Alamry, K. I. Aly, Designed Monomers and Polymers. 2012, 15, 431-463.

http://dx.doi.org/10.1080/1385772X.2012.688325

27. Z. Youming, D. Xinrong, W. Liangcheng, J. Incl. Phenom. Macrocycl. Chem. 2008, 60, 313-319.

http://dx.doi.org/10.1007/s10847-007-9379-z
28. S. Banerjee, S. K. Palit, S. Maiti, J. Polym. Mater. 1992, 9, 219-228.

29. B. K. Mandal, S. Maiti, Eur. Polym. J. 1986, 22, 447-450. http://dx.doi.org/10.1016/0014-3057(86)90005-4

30. D. Nepal, S. Sama, K. E. Geckeler, Macromolecules, 2003, 36, 3800-3802. http://dx.doi.org/10.1021/ma0258410

31. S. B. Park, H. Kim, W. C. Zin, J. C. Jung, Macromolecules, 1993, 26, 1627-1632. http://dx.doi.org/10.1021/ma00059a021

32. O. Catanescu, M.Grigoras, G. Colotin,A. Dobreanu, N. Hurduc, C. I. Simionescu, Eur. Polym. J. 2001, 37, 2213-2216. http://dx.doi.org/10.1016/S0014-3057(01)00119-7

\section{Povzetek}

Pet novih lineranih polimerov na osnovi Schiffovih baz z azometinsko strukturo, etrsko vezjo in podaljšanimi alifatskimi verigami s fleksibilnimi distančniki smo sintetizirali s polikondenzacijo dialdehidov (monomer) $\mathrm{z}$ alifatskimi in aromatskimi diamini. Izkoristki priprave monomerov in polimerov so bili v območju od $75 \%$ do $92 \%$. Polimeri s fleksibilnimi distančniki n-heksana so bili ob segrevanju delno topni v acetonu, kloroformu, THF, DMF in DMSO. Monomere in polimere smo karakterizirali z določanjem tališča, elementno mikroanalizo, FT-IR, ${ }^{1} \mathrm{HNMR}$, UV-VIS spektroskopijo, termogravimetrijo (TG), diferencialno termično analizo (DTA), fluorescenčno emisijo, vrstično elektronsko mikroskopijo (SEM) in meritvami viskoznosti njihovih razredčenih raztopin. 